\title{
Circulation in the Gulf of Khambhat-A Lagrangian Perspective
}

\author{
Aditi Mitra ${ }^{1,2}$, V. Sanil Kumar ${ }^{1, *(1)}$ and V. Simhadri Naidu ${ }^{3}$ \\ 1 Ocean Engineering, CSIR-National Institute of Oceanography (Council of Scientific \& Industrial Research), \\ Goa 403004, India; amitra@nio.org \\ 2 Marine Science Department, Bharathidasan University, Tamil Nadu 620023, India \\ 3 CSIR-National Institute of Oceanography (Council of Scientific \& Industrial Research), Mumbai 400053, \\ India; vsnaidu57@gmail.com \\ * Correspondence: sanil@nio.org; Tel.: +91-832-2450-327
}

Received: 19 November 2019; Accepted: 20 December 2019; Published: 6 January 2020

\begin{abstract}
The circulation of the Gulf of Khambhat (GoK) is studied from a Lagrangian point of view using a 2D numerical model. The model-predicted tide elevation and current speed are in agreement with the observations. Seasonal variations of advection of particles are simulated by releasing 237 particles homogeneously distributed over the Gulf. After one month of simulation, no particles escaped from the GoK except a few from the southern GoK during southwest monsoon (June-September), and the advection of particles was at its maximum in the northern part. Residual eddies are present inside the GoK during the northeast (October-January) and southwest monsoon seasons. Gulf circulation is studied with the combined forcing of tide and wind for different tidal conditions, which had noticeable seasonal difference. The maximum simulated current speeds of 3.4 and $2.8 \mathrm{~m} / \mathrm{s}$ are noticed during southwest monsoon near to Bhavnagar and Dahej respectively, where the tide elevations are maximum indicating that GoK is a tide-dominated system. A seasonal barrier could be found in the southern Gulf, which not only makes the Gulf circulation distinct from that of the Arabian Sea (AS), but also restricts water-mass exchange between the Gulf and AS during ebb condition. As the Gulf is a dump yard for anthropogenic wastes, the present study puts forward an effort to determine the fate of the waste from a hydrodynamic point of view.
\end{abstract}

Keywords: circulation; residual eddies; tidal current; tidal hydrodynamics; Gulf of Khambhat

\section{Introduction}

The western continental shelf of India is varied from south to north, and widens off Mumbai, leading into a strongly converging channel, the Gulf of Khambhat (GoK). The GoK, formerly known as the Gulf of Cambay, is a funnel-shaped indentation, situated between the Saurashtra peninsula and the mainland of Gujarat (Figure 1). The GoK has a width of $80 \mathrm{~km}$ at the mouth and funnels down to $25 \mathrm{~km}$ over a longitudinal reach of $140 \mathrm{~km}$. The gulf is shallow, with a maximum water depth of about $30 \mathrm{~m}$, and the northern part of the gulf is characterised by a water depth of less than $10 \mathrm{~m}$ and large tidal flats [1]. The tides in GoK are of semi-diurnal type, with large diurnal inequality and varying amplitudes, which increase from the south to north along the GoK. The amplification of the tide inside the GoK is due to its shape and varying bottom friction coefficients [2], as well as the large width of the continental shelf off the central west coast of India [3]. In the north Indian Ocean, the maximum tidal range is found in GoK, with an average tidal range of $10 \mathrm{~m}$ near Bhavnagar [4]. Current measurements in GoK indicate a maximum current speed of $3.3 \mathrm{~m} / \mathrm{s}$ and north-northwest flows during flood tide and south-southeast flows during ebb tide [5]. The main rivers that drain into the GoK are the Narmada, Tapi, Mahi and Sabarmati, and these rivers discharge a large amount of 
suspended sediment (more than $1000 \mathrm{mg} / \mathrm{L} / \mathrm{d}$ ) [6], which makes the Gulf more turbid as this oscillates within this region until water flushes it towards the open sea [7]. These rivers discharge a substantial freshwater run-off into the gulf, especially during the monsoon season. The discharge of the Narmada River, which is the major river, ranges between 10,000 and $60,000 \mathrm{~m}^{3} / \mathrm{s}$ during monsoonal floods.

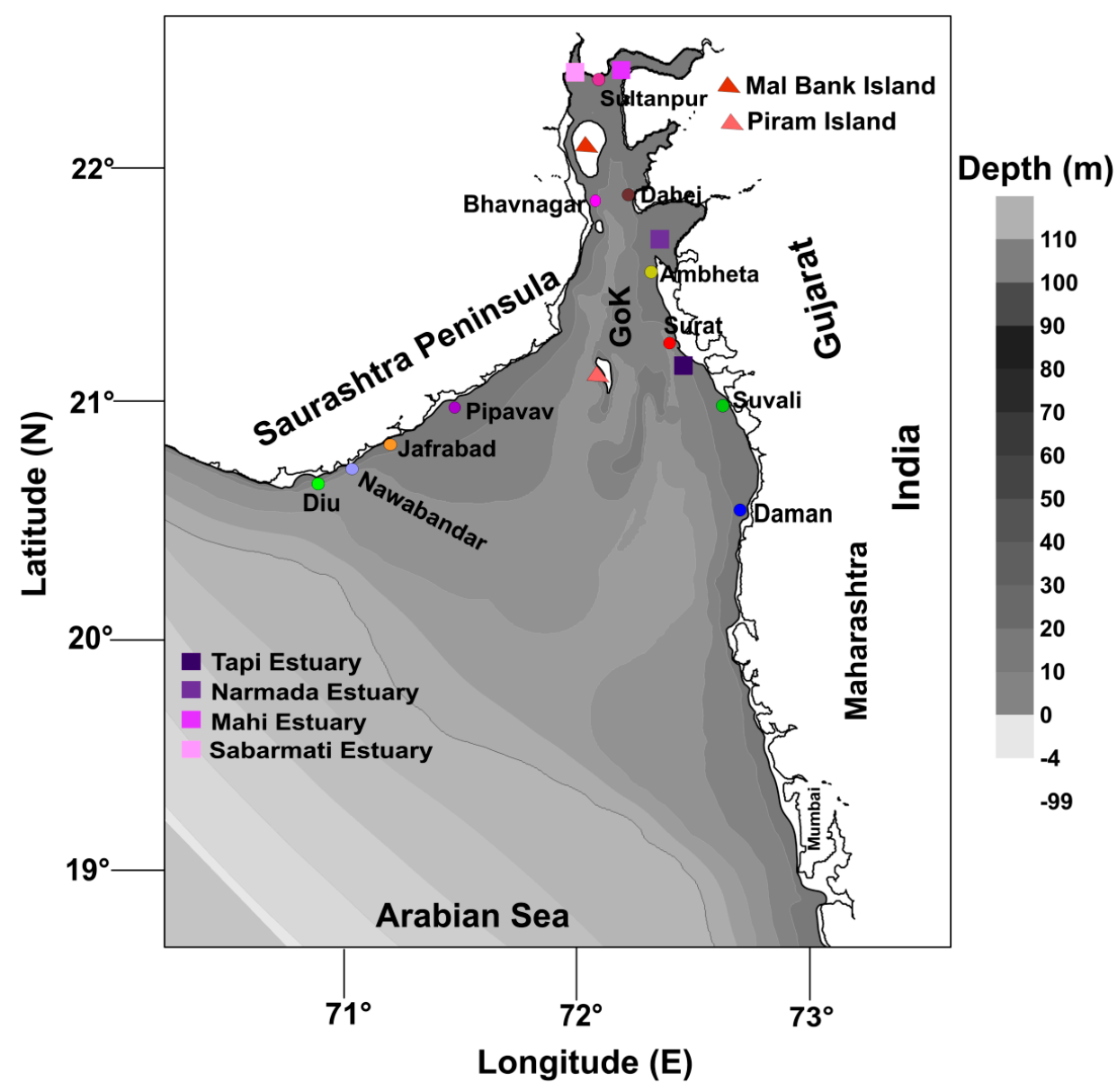

Figure 1. Study area (Gulf of Khambhat and surroundings) showing the bathymetry of the region. Maximum water depth in the model domain is more than $100 \mathrm{~m}$. Total number of grid is $744 \times 850$ and the grid resolution is $500 \mathrm{~m}$. The model extends towards land up to $4 \mathrm{~m}$ above the Chart Datum.

The climate of the study region ranges from semi-arid through tropical steppe in the north to tropical rainy in the south, with an average rainfall exceeding $100 \mathrm{~cm}$ per year in the coastal area [8]. The Gulf is exposed to seasonally reversing wind with winds veering from the southwest (SW) during the summer monsoon (June-September) and from the northeast (NE) during the winter monsoon period (October-January). The period between the winter and summer monsoon is the pre-monsoon period (February-May). Higher wind speeds of up to $21 \mathrm{~m} / \mathrm{s}$ are likely to occur during the SW monsoon [9]. The Gulf is expected to be influenced by large-scale wind-driven circulation [10]. The jet currents in the proximity of the $60 \mathrm{~m}$ depth contour are considered to be the coastal ocean boundary, and do not allow the gulf-water to be adverted/flushed out into the open sea directly [11]. The seasonal variability of GoK is due to the seasonality of the main forcing agents-the Arabian Sea at the Gulf's entrance and the monsoon wind regime. The Gulf is homogeneous and displays a one-layer structure, and currents at deeper depths inside the Gulf follow the same velocity pattern as the surface due to the shallowness of the depths and the high tidal amplitudes [11].

Study of the tidal hydrodynamics of a coastal area, i.e., gulfs, estuaries, creeks, bays, lagoons, etc., are of paramount importance, as these data will be the baseline of any coastal development of that particular area. The tidal hydrodynamics of the Gulf of California were studied by Marinone [12], 
who inferred that the tide of that area was in oscillation with the Pacific Ocean and that the semi-diurnal constituents were near resonance, with head amplitudes four times larger than those at the mouth. Further study concluded that a depth-averaged circulation could often be used to have an idea about the advection of the passive pollutants [12]. Sheng and Wang [13] used a single-domain coastal circulation model to study the non-linear dynamics of the barotropic tidal circulation in Lunenberg Bay. A study by Allahdadi et al. [14] surmised that currents in the Atchafalaya shelf follow the general circulation pattern of the Louisiana coast and are influenced by seasonal wind, tides, river discharge, and outer-shelf variations induced by the loop current eddies. A coupled hydrodynamic/suspended sediment transport model was developed and successfully applied to Cleveland Bay, Australia [15]. Tattersall et al. [16] applied 2D depth-averaged models to simulate the tidal currents and suspended sediment concentrations in the Tamar estuary, England.

Understanding the circulation characteristics of the GoK is extremely important, as hydrodynamics have a direct impact on the design of any engineering infrastructure built in this area. The tidal strength is an important agent in driving and modulating net circulation in a semi-enclosed water body. Several economic activities (e.g., shipping, oil and gas extraction), as well as flora and fauna, can be directly or indirectly influenced by the tidal variations and associated circulation and the possible changes to those processes. Anthropogenic activities or long-term natural processes can affect those processes, with often drastic and unexpected consequences. Studies on hydrodynamics are also essential to understanding the interaction of the coastal and inland water in terms of the physical processes as well as the exchange of nutrients or pollutants between the two water bodies. Longuet-Higgins [17] showed the limitations of a Eulerian point of view in explaining the long-term transport of water particles: he defined the mass transport velocity as the sum of the Eulerian residual current and the Stokes drift by carrying out a first-order approximation of the Lagrangian residual velocity. Numerical methods based on particle tracking enable calculation of the Lagrangian residual circulation for strongly non-linear systems [18]. The ocean exhibits a huge range of dynamical motions, extending scales from millimetres to thousands of kilometres. Lagrangian analysis is a powerful way of analysing the output of ocean circulation models and other ocean velocity data. This method employs an ensemble of passive Lagrangian particles of zero spatial extent whose trajectories are determined by the velocity field [19]. A large number of industries are present on both banks of the Gulf, discharging an enormous amount of treated effluent into the sea. At present, the fate of the particles discharged in the Gulf is not known. The Lagrangian analysis along with the hydrodynamics could provide an insight to the fate of the sewage/industrial effluent released in the Gulf.

Thus, the main objective of this work is to study the seasonal variation of depth-averaged Lagrangian circulation of the GoK using a calibrated 2D numerical model. Section 2 presents the materials and methods.

\section{Materials and Methods}

\subsection{Hydrodynamic Model}

The currents measured off Dahej at $12 \mathrm{~m}$ water depth show that the currents are similar near the surface and the bottom (Figure 2), indicating that the water is vertically well mixed. An unsteady and two-dimensional vertically integrated shallow-water equation for continuity and momentum balance given by Stoker [20] was used to obtain the tides and tide-induced circulation in the GoK. In this study, the 2D model developed for simulating Thane creek tidal circulation [21] and to determine the flushing characteristics of Amba estuary [22] was applied to the GoK. The model is barotropic, based on shallow water equations, and neglects horizontal diffusion terms in the momentum equations. Due to the seasonal wind reversal in the study region, wind stress terms are introduced in the model. Wetting and drying in shallow areas were modelled. 


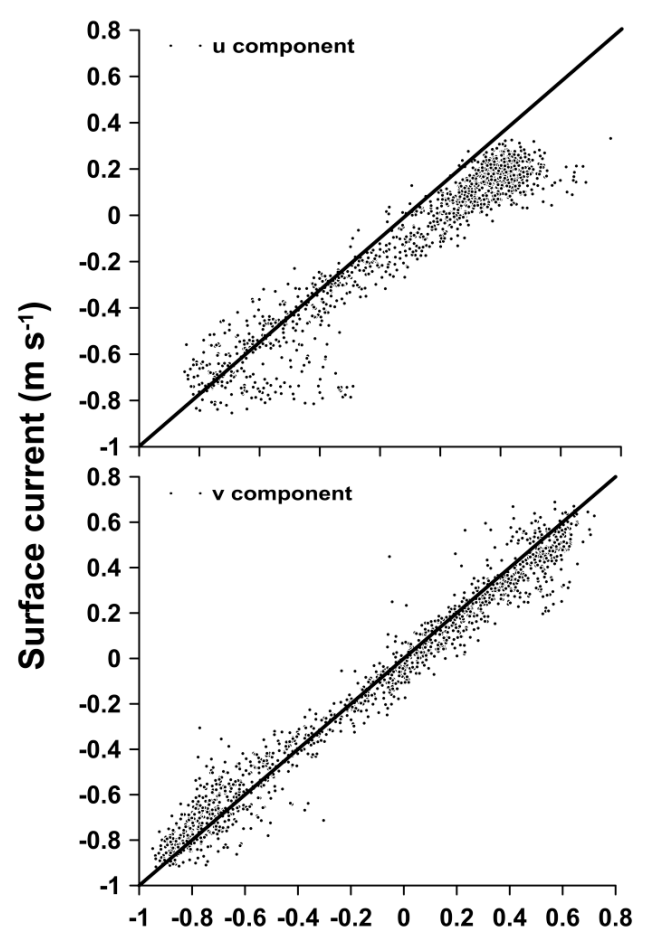

Bottom current $\left(\mathrm{m} \mathrm{s}^{-1}\right)$

Figure 2. Near surface and bottom ( $2 \mathrm{~m}$ above seabed) currents measured by recording Doppler current profiler (RDCP) off Dahej at $12 \mathrm{~m}$ water depth from 18 to 28 March 2016.

(a) Continuity and mass balance

$$
\frac{\partial \eta}{\partial t}+\frac{\partial(H U)}{\partial x}+\frac{\partial(H V)}{\partial y}=(\eta+h) m_{v}
$$

where $\eta=H-h, t=$ time coordinate, $x, y=$ set of horizontal, mutually orthogonal Cartesian coordinates, $H=$ total instantaneous water depth, $U, V=$ horizontal velocity components in $x$ and $y$ direction respectively, $m_{v}=$ vertically integrated average rate of mass infection or withdrawal of fluid per unit volume divided by the fluid density, $h=$ the depth of water measured positively downwards from the reference datum plane.

(b) Momentum balance equations

The vertically integrated momentum balance equations for a shallow water body are given by

$$
\begin{aligned}
& \frac{\partial U}{\partial t}+U \frac{\partial U}{\partial x}+V \frac{\partial U}{\partial y}=-g \frac{\partial \eta}{\partial x}-\frac{1}{\rho} \frac{\partial P}{\partial x}+\Omega V+\frac{C_{w} W^{2}}{(\eta+h)} \cos \theta-\frac{C_{f}\left(U^{2}+V^{2}\right)^{\frac{1}{2}}}{(\eta+h)} U+S_{u} \\
& \frac{\partial V}{\partial t}+U \frac{\partial V}{\partial x}+V \frac{\partial V}{\partial y}=-g \frac{\partial \eta}{\partial y}-\frac{1}{\rho} \frac{\partial P}{\partial y}-\Omega U+\frac{C_{w} W^{2}}{(\eta+h)} \sin \theta-\frac{C_{f}\left(U^{2}+V^{2}\right)^{\frac{1}{2}}}{(\eta+h)} V+S_{v}
\end{aligned}
$$

where $g=$ acceleration due to gravity, $\eta=$ tide elevation, $\rho=$ fluid mass density, $P=$ fluid pressure $(P=H \rho g), \Omega=$ Coriolis parameter, $C_{w}=$ wind stress coefficient, $W=$ wind speed, $\theta=$ wind angle measured from the positive direction of $x$ towards the positive direction of $y$-axis, $C_{f}=$ bottom friction coefficient, $S_{u}$ and $S_{v}=$ average rate of momentum generated or dissipated per unit volume derived by the mass density of water in the $x$ and $y$ directions, respectively.

Equations (1)-(3) are solved using the Alternate Direction Implicit (ADI) scheme, which is a finite difference method for solving parabolic, hyperbolic and elliptic partial differential equations with finite difference grid systems. Horizontal diffusion terms in the momentum balance were neglected, 
since their contributions were small compared with the other terms. The contour $-4 \mathrm{~m}$ in the bathymetry describes the inter-tidal region that behaves as part of the landmass during high tide and as a water mass during low tide. Thus, the model considers its wetting conditions during high water, and its drying during low water. The input data were smoothed using the spline function to obtain the tide at closer intervals. The governing equations were solved with the initial and boundary conditions on a staggered grid system as described by Leendertse [23]. The tides at the intersection of two straight open boundaries, i.e., the northwest and southwest corners of the model domain, were derived from the OSU (Oregon State University) Global Tidal Model [24] and the tide at the other two corners were model-based. The model domain with the grid resolution of $500 \mathrm{~m}$ was tilted by an angle of $45^{\circ}$ for ease of giving the model input. The model results are represented by the actual geographic location of the system.

The bottom friction $\left(C_{f}\right)$ was parameterized in terms of coefficient of Chezy using the formula, $C_{f}=$ $(1 / 32) \times\left[\log _{10}(14.8 H) / K\right]^{-2}$, where $K$ is a roughness length. As $C_{f}$ is a function of depth, varying bottom friction values were applied in different regions of the model domain for the calibration and validation of the model. The magnitudes of the bottom friction coefficients for different area is taken from Sathish and Balaji [25]. The stability of the numerical scheme is governed by $\Delta t<\Delta x / \sqrt{2 g H_{\max }}$, where $\Delta x$ is grid size in meters and $\Delta t$ is the time step in seconds and $g$ is the acceleration due to gravity and $H_{\max }$ is the maximum depth in the model domain. When $H_{\max }$ is $100 \mathrm{~m}$ and $\Delta x$ is $500 \mathrm{~m}$, the $\Delta t$ is 12 s. It was assumed that the sea was initially at rest, i.e., at $t=0, U=V=0$. Since the model was initially at rest, it took more than $15 \mathrm{~h}$ for the model to stabilize. Thus, the first day of data from each model simulation was discarded. The northern boundary of the model domain was closed. The model simulation was done by applying tides at Mumbai and Veraval along with the intersection of two straight open boundaries, i.e., at the northwest and southeast corners of the rectangular model domain (i.e., boundary tide at the eastern, southern and western boundary of the model domain). For ease of simulation, the model domain was rotated $45^{\circ}$ in anti-clockwise direction. The results are represented using the actual geographical position of the area. A negative value in the bathymetry figure denotes land area. The model extends up to the inter-tidal area of the domain $(-4 \mathrm{~m}$ in the bathymetry figure). Reanalysis data of zonal and meridional components of wind speed at $10 \mathrm{~m}$ height at one hour interval with a resolution of $0.25^{\circ} \times 0.25^{\circ}$ for the entire study area were obtained from NCEP/NCAR [26] to use them as the model input for determining the influence of wind on sea level and currents. These data are provided by the NOAA-CIRES Climate Diagnostics Center, Boulder, Colarado at http://www.cdc.noaa.gov/. The river discharge data of four major rivers (Narmada, Tapi, Mahi and Sabarmati) used in this study were provided by the Central Water Commission (CWC), New Delhi. Due to the high dynamicity of the area, GoK was assumed to be a one-layer system, and hence standard seawater density was used for model simulation in the entire model domain.

\subsection{Lagrangian Circulation}

Lagrangian circulation was analysed using a particle tracking method by releasing particles at a fixed time, tracking the path of these particles and the time when they reached the boundary, and was performed in a 2-D mode, using a 4th order Runge-Kutta (RK) scheme for particle advection. The trajectories of the particles were obtained by time-integrating the horizontal velocity field. Lagrangian circulation was calculated using an equation [27] that has previously been used by Naidu et al. [22]. 4-point linear interpolation was adopted to calculate the velocity at an arbitrary point.

$$
\bar{x}(t+\Delta t)=\bar{x}(t)+U \Delta t
$$

where $\bar{x}$ is the particle's position, $\Delta t=$ time step. In this work, the diffusion term was neglected.

\subsection{Residual Circulation}

The differences between the simulated currents and those derived from tidal harmonics were averaged over one lunar cycle to compute the steady residual circulation or mean currents. The model 
was run for one lunar tidal cycle (29.5 days) by storing $U$ and $V$ components of velocity at each grid at 20-min intervals for three seasons. Using the following equation, the residual velocity $R_{v}$ is estimated.

$$
R_{v}=\frac{1}{T} \int_{0}^{T} U \Delta t
$$

The net velocity is calculated by integrating the velocity components [22].

\subsection{Model Calibration for Hydrodynamics}

Tide and current data from the model were compared with measured data for locations at Surat (Figures 3a and 4a), Dahej (Figures $3 b$ and $4 b$ ) and Bhavnagar (Figures $3 c$ and $4 c$ ), which are inside the GoK and the details of the tide and current used are presented in Table 1. Bias and Root Mean Square Error were calculated for the observed and predicted tide elevation and current speed are presented in Table 1. The bias values of $0.09,0.04$ and $0.03 \mathrm{~m} / \mathrm{s}$ for currents at Surat, Dahej and Bhavnagar show that the modelled and observed datasets are in agreement with each other. The positive bias values indicate that the predicted data slightly over-estimated the observed datasets. At first, single-valued friction co-efficient was applied for the entire model domain, and the model results were found to differ with the observed one. After calibration of the model by comparing simulated and observed Eulerian currents, the bottom friction coefficients were found to be variable from place to place. Neutrally buoyant floats, released off Dahej and Bhavnagar, were used to compare the simulated Lagrangian tracks in these areas. Furthermore, the Lagrangian tracks were used for the validation of the model (Figure 5). The validation was done with respect to the entire model domain, but a small section is presented for better delineation. The advection of the buoys was found to be $41 \mathrm{~km}$ and $26 \mathrm{~km}$ during flood and ebb conditions, respectively, which is well-captured by the model. It could clearly be noticed that the flood is much stronger than ebb in the Gulf. On average, the modelled track points were $260 \mathrm{~m}$ and $267 \mathrm{~m}$ ahead of the observed trails under ebb and flood conditions, respectively. No stratification was revealed by the RDCP data moored at the eastern GoK (Dahej) (Figure 2), and hence, a 2D numerical model was applied in this work instead of a 3D model.

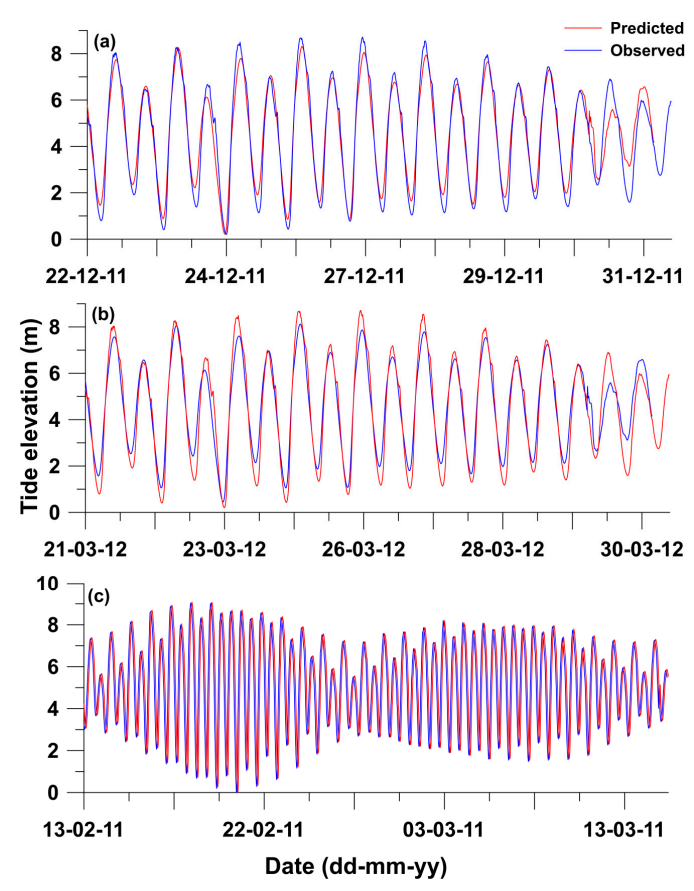

Figure 3. Comparison of observed and predicted tide elevation at three locations of GoK; (a) Dahej, (b) Surat, and (c) Bhavnagar. The location details, along with comparison statistics, are presented in Table 1. 

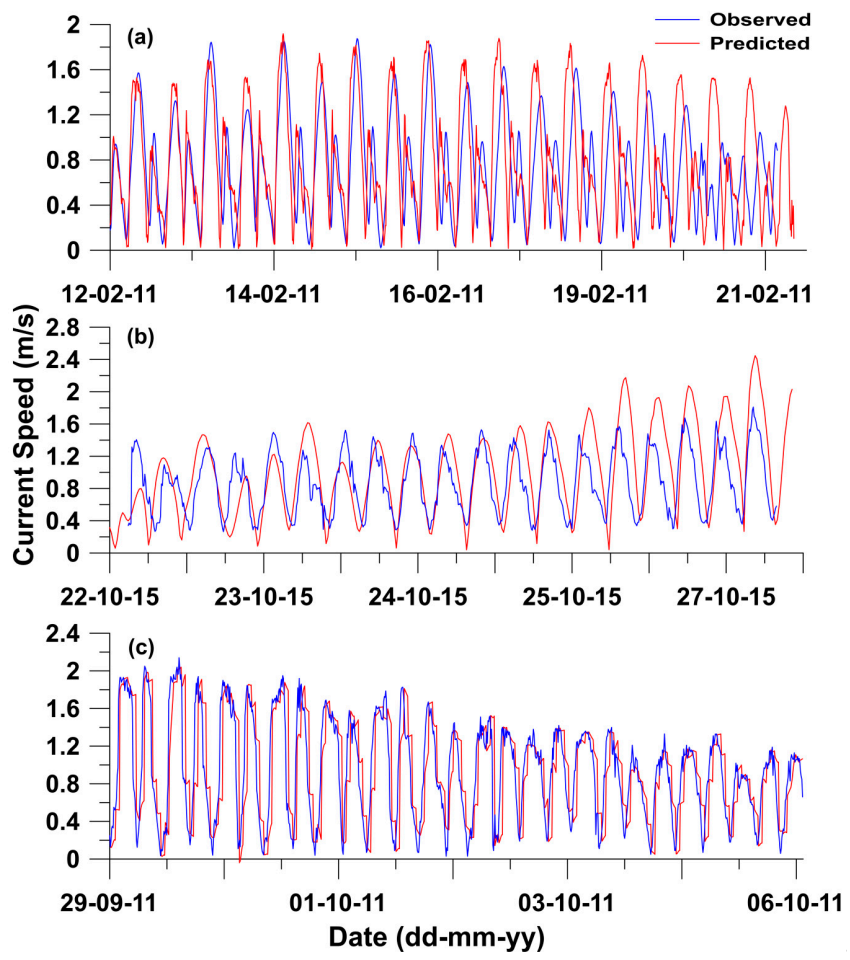

Figure 4. Comparison of observed and predicted current speed at three locations of GoK; (a) Surat, (b) Dahej, and (c) Bhavnagar. The location details, along with comparison statistics, are presented in Table 1.

Table 1. Details of data used for calibration of tide and current.

\begin{tabular}{|c|c|c|c|c|}
\hline \multicolumn{5}{|c|}{ Tide } \\
\hline Location & Coordinate & Duration & Bias (m) & RMSE (m) \\
\hline Dahej & $\begin{array}{l}21^{\circ} 39^{\prime} 9.1^{\prime \prime} \mathrm{N} \\
72^{\circ} 33^{\prime} 17.4^{\prime \prime} \mathrm{E}\end{array}$ & 22 October 2015-01 November 2015 & 0.05 & 0.11 \\
\hline Surat & $\begin{array}{l}21^{\circ} 04^{\prime} 4.7^{\prime \prime} \mathrm{N} \\
72^{\circ} 37^{\prime} 41.3^{\prime \prime} \mathrm{E}\end{array}$ & 22 December 2011-01 January 2012 & 0.04 & 0.19 \\
\hline Bhavnagar & $\begin{array}{l}21^{\circ} 27^{\prime} 25.0^{\prime \prime} \mathrm{N} \\
72^{\circ} 15^{\prime} 32.2^{\prime \prime} \mathrm{E}\end{array}$ & 13 February 2011-15 March 2011 & 0.035 & 0.012 \\
\hline \multicolumn{5}{|c|}{ Current } \\
\hline Location & Coordinate & Duration & $\operatorname{Bias}(\mathrm{m} / \mathrm{s})$ & RMSE (m/s) \\
\hline Dahej & $\begin{array}{l}21^{\circ} 39^{\prime} 9.1^{\prime \prime} \mathrm{N} \\
72^{\circ} 33^{\prime} 17.4^{\prime \prime} \mathrm{E}\end{array}$ & 22 October 2015-01 November 2015 & 0.04 & 0.58 \\
\hline Surat & $\begin{array}{l}21^{\circ} 04^{\prime} 2.4^{\prime \prime} \mathrm{N} \\
72^{\circ} 37^{\prime} 39.7^{\prime \prime} \mathrm{E}\end{array}$ & 12 February 2013-22 February 2013 & 0.09 & 0.44 \\
\hline Bhavnagar & $\begin{array}{l}21^{\circ} 27^{\prime} 2.6^{\prime \prime} \mathrm{N} \\
72^{\circ} 15^{\prime} 47.2^{\prime \prime} \mathrm{E}\end{array}$ & 29 September 2011-6 October 2011 & 0.03 & 0.04 \\
\hline
\end{tabular}




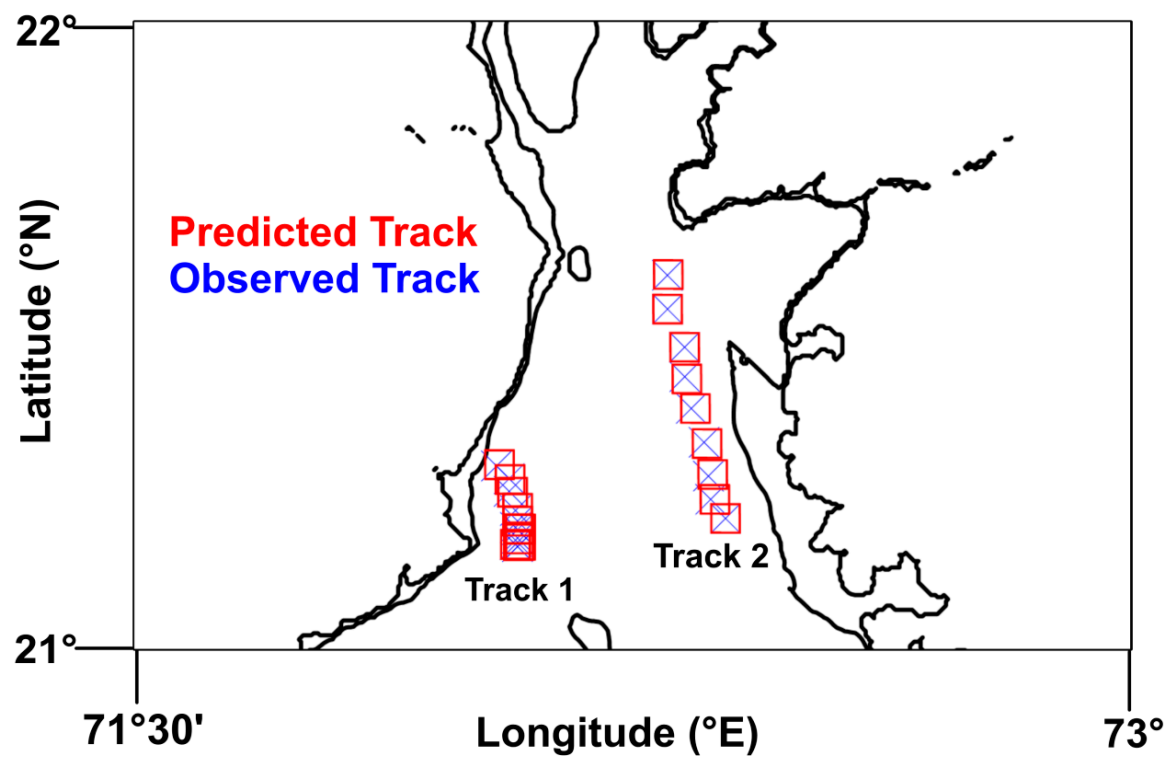

Figure 5. Comparison of observed and predicted Lagrangian particle track; Track 1 represents ebb condition, while Track 2 represents flood condition.

\section{Results}

\subsection{General Circulation}

The model was run for different scenarios, viz., the tide-driven, wind-driven and the combined tide and wind-driven circulation of GoK for three typical months of three seasons, i.e., January (NE-monsoon), May (pre-monsoon) and July (SW-monsoon), with different tidal conditions, viz., neap ebb, neap flood, spring ebb, and spring flood. The circulation driven by the combined forcing of tide and wind are presented in the manuscript (Figures 6 and 7). A barrier-like feature, separating inner and outer GoK, could be identified under neap ebb conditions during the NE-monsoon (red line in Figure 6a), where the clear dissimilarity between Gulf circulation with that of the Arabian Sea was noticed. This type of formation was absent for the flood condition of neap and spring tide of the same season (Figures $6 \mathrm{~b}$ and $7 \mathrm{~b}$ ). During the NE-monsoon, the maximum current speed $(2.8 \mathrm{~m} / \mathrm{s})$ was identified inside the Gulf near to the Narmada mouth during spring peak flood conditions (Figure $7 \mathrm{~b}$ ). Under spring ebb conditions, the barrier shifted northward, but it was not as significant as neap tidal conditions. The barrier formation could be noticed during the pre-monsoon season in ebb condition of neap and spring tide (Figures $6 \mathrm{c}$ and $7 \mathrm{c}$ ). The barrier shifted southward in this season, running between Pipavav in the west and Daman in the east. The barrier was absent during the flood condition of spring tide (Figure 7d). Anti-cyclonic eddy was present off Pipavav during the flood condition of spring and neap tide. Maximum current speed of $2.4 \mathrm{~m} / \mathrm{s}$ could be noticed at Narmada mouth during spring peak ebb condition. A similar type of barrier formation between Pipavav and Daman could be identified under neap ebb conditions (Figure 6e) during SW-monsoon. An anti-cyclonic eddy was identified off Pipavav under flood conditions of neap tide (Figures 6e and 7e) during the pre-monsoon, which was found to be absent in the ebb condition. A maximum current speed of $3.4 \mathrm{~m} / \mathrm{s}$ was noticed for the spring flood condition during SW-monsoon.

Tide-driven circulation was obtained by omitting the wind in the model input, and that was found to be quite similar to the combined tide and wind-driven circulation where the formation of the barrier separating the outer and inner Gulf was also visible during the neap ebb condition in pre-monsoon and SW-monsoon, while in case of NE-monsoon, the barrier was noticed further northward, at the central GoK. Under neap conditions, the barrier could be found for the pre-monsoon season in flood conditions. The tide-driven circulation during the NE-monsoon revealed that a maximum current speed was found during the spring flood condition inside the Gulf with an average magnitude of 
$2.2 \mathrm{~m} / \mathrm{s}$. A clear barrier formation was noticed during the pre-monsoon season under neap ebb conditions, and the barrier shifted further downward under spring ebb conditions. The maximum current speed in this season was found under spring flood conditions. A barrier-like formation could be noticed under the flood conditions of spring and neap tide, but it was not easily distinguishable. The maximum tide-driven current speed of $2.8 \mathrm{~m} / \mathrm{s}$ was noticed during SW-monsoon.

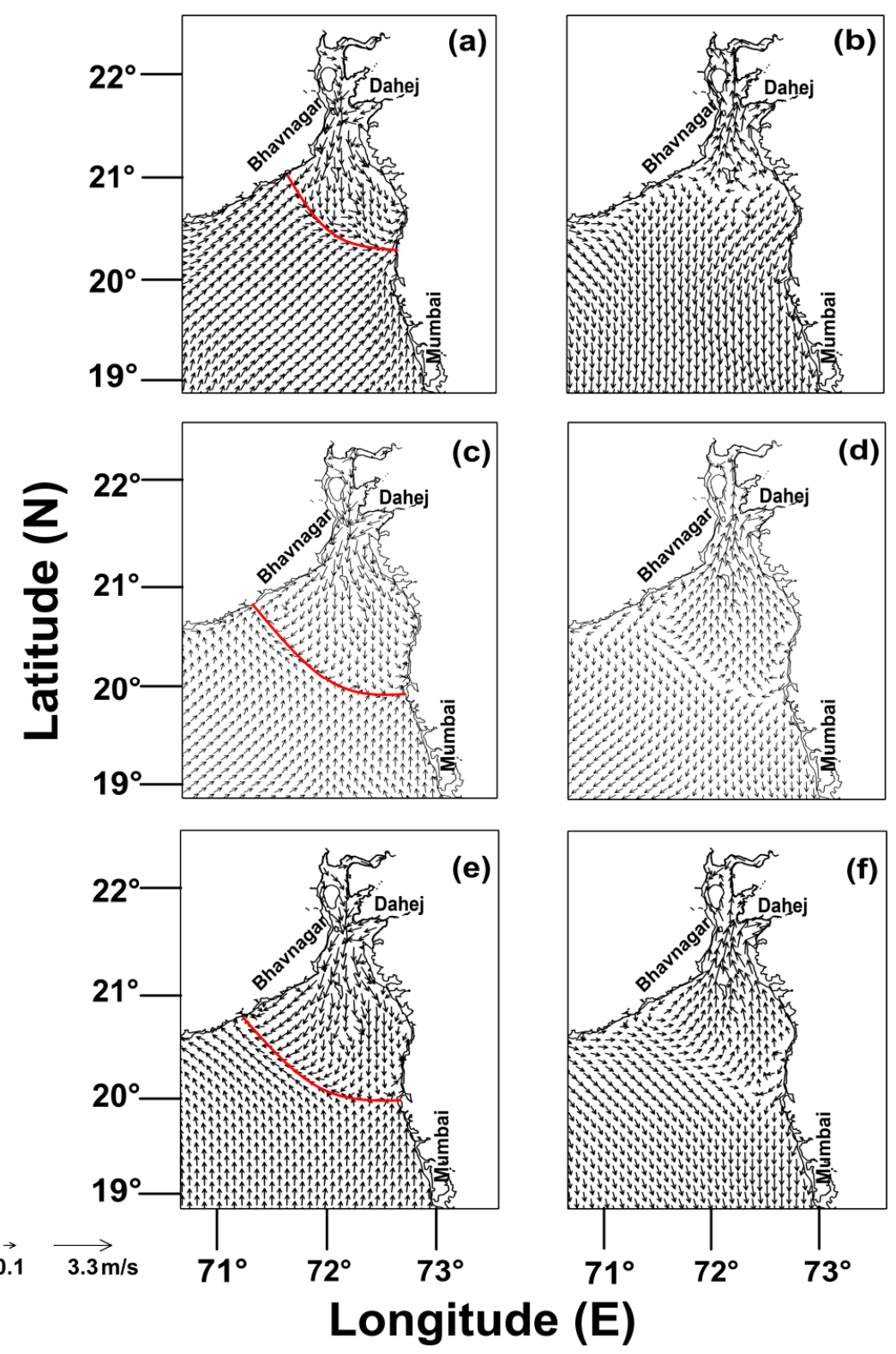

Figure 6. Circulation driven by combined action of tide and wind for various seasons under neap tidal conditions: (a) neap ebb for NE-monsoon, (b) neap flood for NE-monsoon, (c) neap ebb for pre-monsoon, (d) neap flood for pre-monsoon, (e) neap ebb for SW-monsoon, (f) neap flood for SW-monsoon; red line denotes the barrier. 


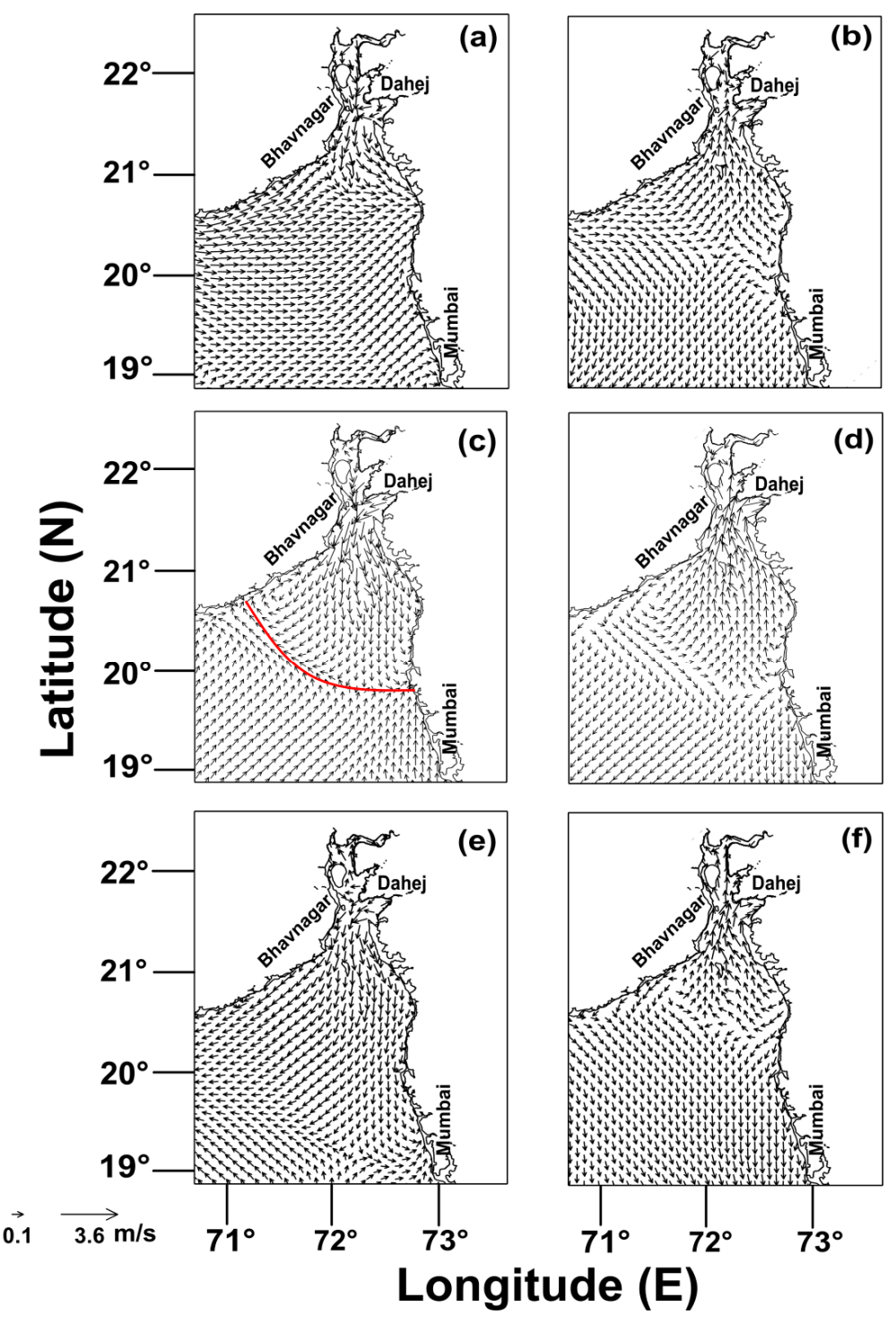

Figure 7. Circulation driven by combined action of tide and wind for various seasons in the spring tidal condition: (a) spring ebb for NE-monsoon, (b) spring flood for NE-monsoon, (c) spring ebb for pre-monsoon, (d) spring flood for pre-monsoon, (e) spring ebb for SW-monsoon, (f) spring flood for SW-monsoon; red line denotes the barrier.

The wind-driven circulation was calculated by using only the wind as the model input, and the circulation was completely different from that of the tide-driven or the combined circulation. During the SW-monsoon, very small eddy structures were visible in and outside the Gulf. An eddy-like structure could be noticed off Bhavnagar in the spring ebb condition, which was found to be absent for the spring flood. Wind-driven eddy formation could be noticed in both the tidal scenarios of the neap tide in the south-western GoK. This kind of formation could be visible off Mumbai for the ebb and flood conditions of neap tide and the also for the spring ebb condition. A maximum current speed of $1.5 \mathrm{~m} / \mathrm{s}$ was observed inside the Gulf at the mouth of Narmada estuary near to Dahej during the spring flood condition. Eddy formations were absent in the wind-driven circulation during NE-monsoon, except for a structure which is formed during the spring flood condition in the central GoK. A maximum current speed of $1.25 \mathrm{~m} / \mathrm{s}$ was found in the northern GoK during the neap flood condition. Maximum current speed of $1.15 \mathrm{~m} / \mathrm{s}$ was obtained in the middle of the Gulf under the spring peak flood conditions of the pre-monsoon season. The wind-driven eddy was noticed under the neap peak flood conditions in the south-western GoK. 
Three locations were selected in the northern (mouth of Mahi estuary), eastern (mouth of Narmada estuary) and western GoK (off Bhavnagar), where simulated U-V components of currents were obtained for different seasons to understand the contributions of tide and wind in the combined circulation of GoK (Figures 8-10). The results suggest that the maximum velocity of $1.44 \mathrm{~m} / \mathrm{s}$ was due to the combined action of tide and wind during the SW-monsoon in the eastern Gulf, where the dominance of the U-component of current was observed while V-component dominates in the other two locations. Tidal action dominates the wind action during the NE-monsoon and pre-monsoon seasons, but the wind action contributes significantly during the SW-monsoon season. It can be noticed that there is a considerable difference between the tide-driven current and the combined tide and wind-driven current during the SW-monsoon (Figure 8), which was absent for the other two seasons (Figures 9 and 10). Wind speed of more than $2 \mathrm{~m} / \mathrm{s}$ prevailed during $\mathrm{SW}$-monsoon, and as a consequence, the current speed had a magnitude of around $2.5 \mathrm{~m} / \mathrm{s}$. Wind action is strong enough even during the NE-monsoon with a maximum U-component velocity of $0.66 \mathrm{~m} / \mathrm{s}$ at the western Gulf. The mean wind speed had magnitude of more than $1 \mathrm{~m} / \mathrm{s}$ during this period but its impact on current speed was found to be less. Minimum wind-driven U-component velocity of $0.08 \mathrm{~m} / \mathrm{s}$ was found in the eastern Gulf during pre-monsoon season and the contribution of wind towards the current speed was found to be negligible during this period. In each season, the maximum current speed is recorded for the combined circulation driven by both tide and wind in the eastern gulf. The minimum current speed was obtained for the northern GoK in each of the seasons. It could also be noticed from the figures (Figures 8-10) that the tidal forcing dominates the wind forcing in the hydrodynamics of GoK. The study illustrates that the dominance of tide in GoK is much more than wind when considering the barotropic circulation.
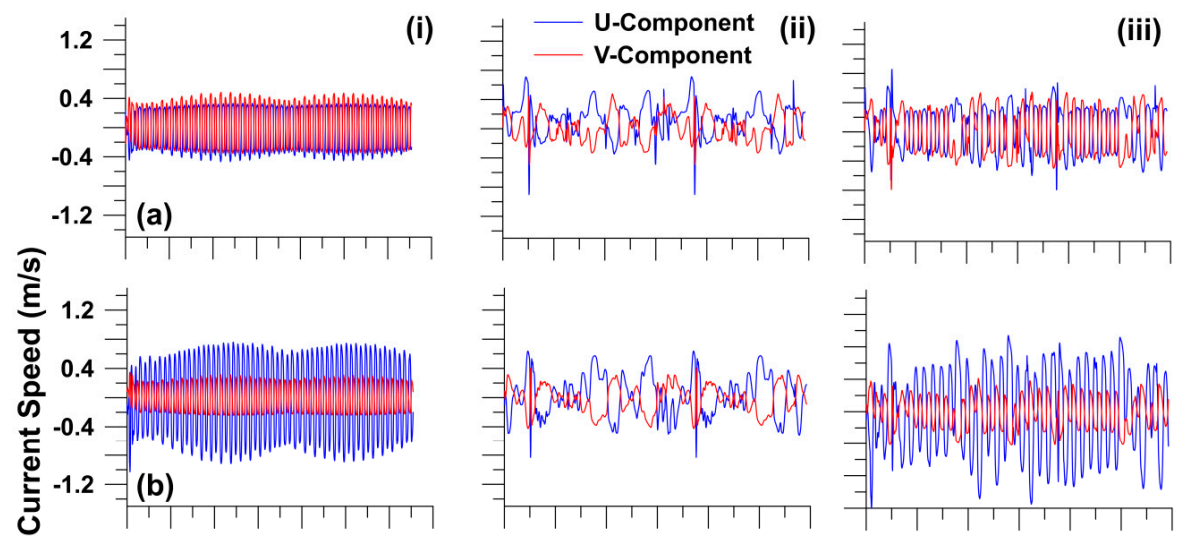

(iii)
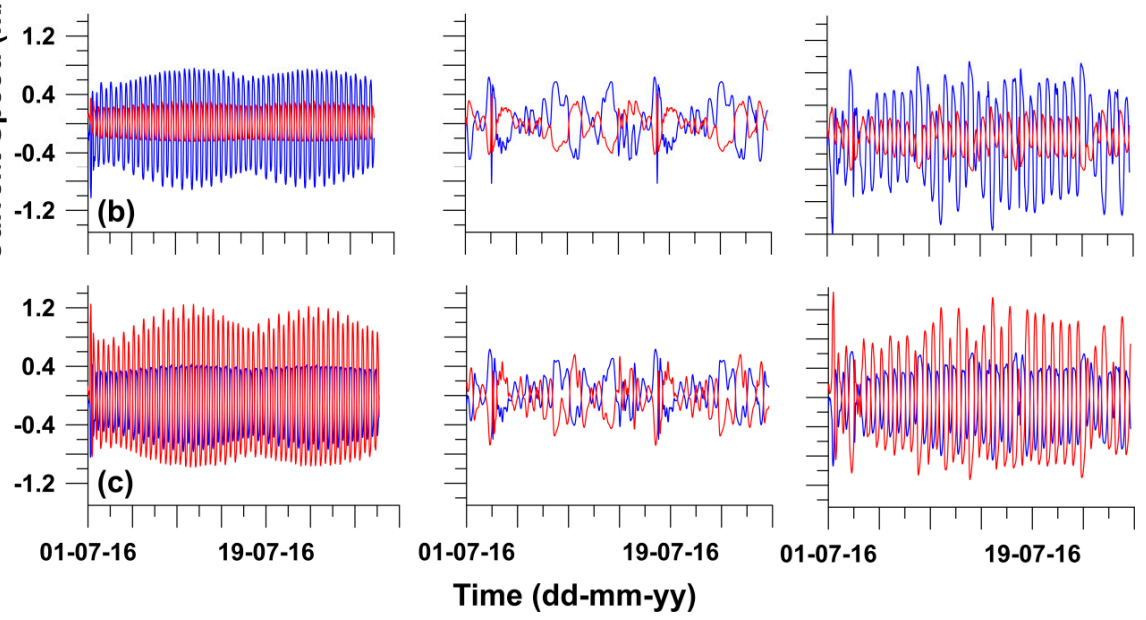

Figure 8. Time series of currents in SW-monsoon forced with (column-wise): (i) only tide, (ii) only wind, and (iii) tide and wind; for (row-wise) (a) northern Gulf, (b) eastern Gulf, and (c) western Gulf. 


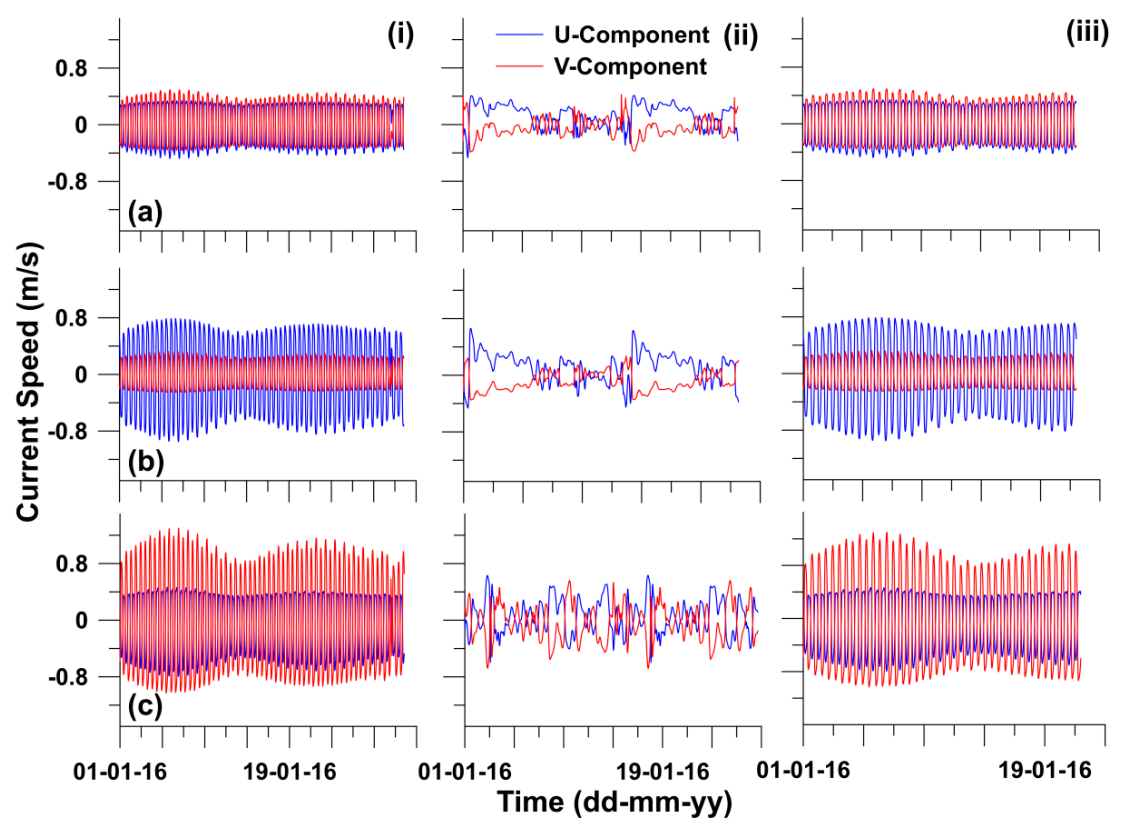

Figure 9. Time series of currents in NE-monsoon forced with (column-wise): (i) only tide, (ii) only wind, and (iii) tide and wind; for (row-wise) (a) northern Gulf, (b) eastern Gulf, and (c) western Gulf.

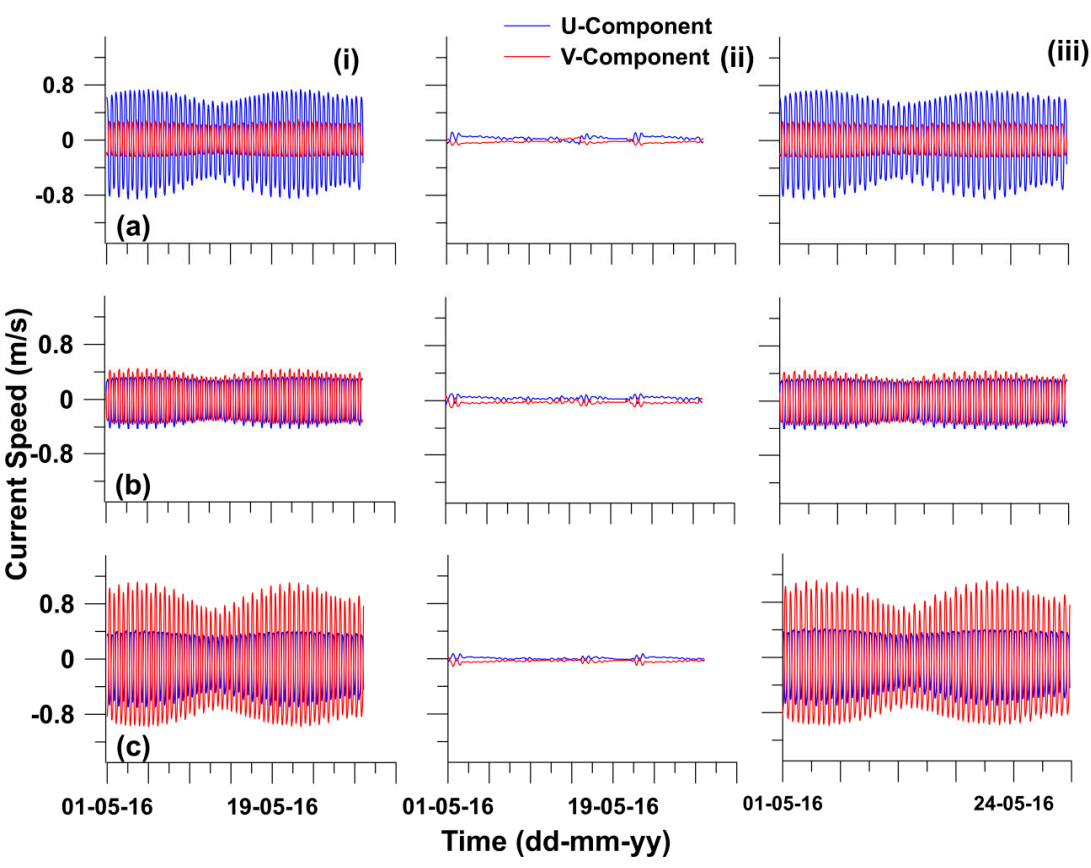

Figure 10. Time series of currents in pre-monsoon forced with (column-wise): (i) only tide, (ii) only wind, and (iii) tide and wind; for (row-wise) (a) northern Gulf, (b) eastern Gulf, and (c) western Gulf.

Areas like GoK, where current speed is high, are potential sites for the extraction of current energy. Power can be generated commercially if the mean peak current exceeds $2 \mathrm{~m} / \mathrm{s}$ [28]. The current speed exceeds $1 \mathrm{~m} / \mathrm{s}$ in the western GoK (off Bhavnagar) for $40.5 \%$ during the southwest monsoon and around $20 \%$ during the remaining period. Meanwhile, in the northern GoK (mouth of Mahi estuary), currents are low and exceed $1 \mathrm{~m} / \mathrm{s}$ for only $0.4 \%$ of the year. In the eastern GoK (mouth of Narmada estuary), for $10 \%$ of the year, the current speed is more than $1 \mathrm{~m} / \mathrm{s}$ (Table 2). 
Table 2. Percentage of time when the current speed is more than $0.5 \mathrm{~m} / \mathrm{s}$ and more than $1 \mathrm{~m} / \mathrm{s}$ in different seasons at 3 selected locations.

\begin{tabular}{ccccccc}
\hline \multirow{2}{*}{ Location } & \multicolumn{3}{c}{ Current Speed $>\mathbf{0 . 5} \mathbf{~ m} / \mathbf{s}$} & \multicolumn{3}{c}{ Current Speed $>\mathbf{1 ~ m / s ~}$} \\
\cline { 2 - 7 } & $\begin{array}{c}\text { Southwest } \\
\text { Monsoon }\end{array}$ & $\begin{array}{c}\text { Northeast } \\
\text { Monsoon }\end{array}$ & Pre-Monsoon & $\begin{array}{c}\text { Southwest } \\
\text { Monsoon }\end{array}$ & $\begin{array}{c}\text { Northeast } \\
\text { Monsoon }\end{array}$ & Pre-Monsoon \\
\hline Eastern GoK & 76.0 & 66.0 & 51.0 & 14.1 & 12.8 & 5.4 \\
Northern GoK & 22.0 & 13.5 & 11.2 & 0.4 & - & - \\
Western GoK & 77.0 & 67.0 & 58.6 & 40.5 & 20.1 & 18.8 \\
\hline
\end{tabular}

The influence of the Narmada river discharge was found to be noticeable from the magnitude of the U-component of current speed, which exceeded the magnitude of the V-component near to the Narmada mouth. To understand the horizontal extent of the river discharge, three locations were selected - central GoK, Narmada mouth, and southern GoK-to obtain the U-V component of current speed at these locations during SW-monsoon. In the central and southern GoK (Figure 11a,c), the dominance of the V-component was observed, but near to the Narmada mouth, it was the opposite (Figure 11b). Thus, it could be inferred that the influence of Narmada discharge on the circulation of GoK is quite a localized phenomenon, and it does not impact the overall circulation of GoK. The area of extent of the river discharge was determined by obtaining the U-V components at different locations, starting from Narmada mouth towards offshore (not shown in the figure). The U-component was predominant at the Narmada mouth and it was found that at a distance of $13 \mathrm{~km}$ from the river mouth, the V-component came into action, and from that point onwards, the dominance of the V-component was observed. This result also manifests the limiting extent of the Narmada discharge into the overall circulation of GoK. Thus, horizontal stratification was not taken into consideration in the present study.

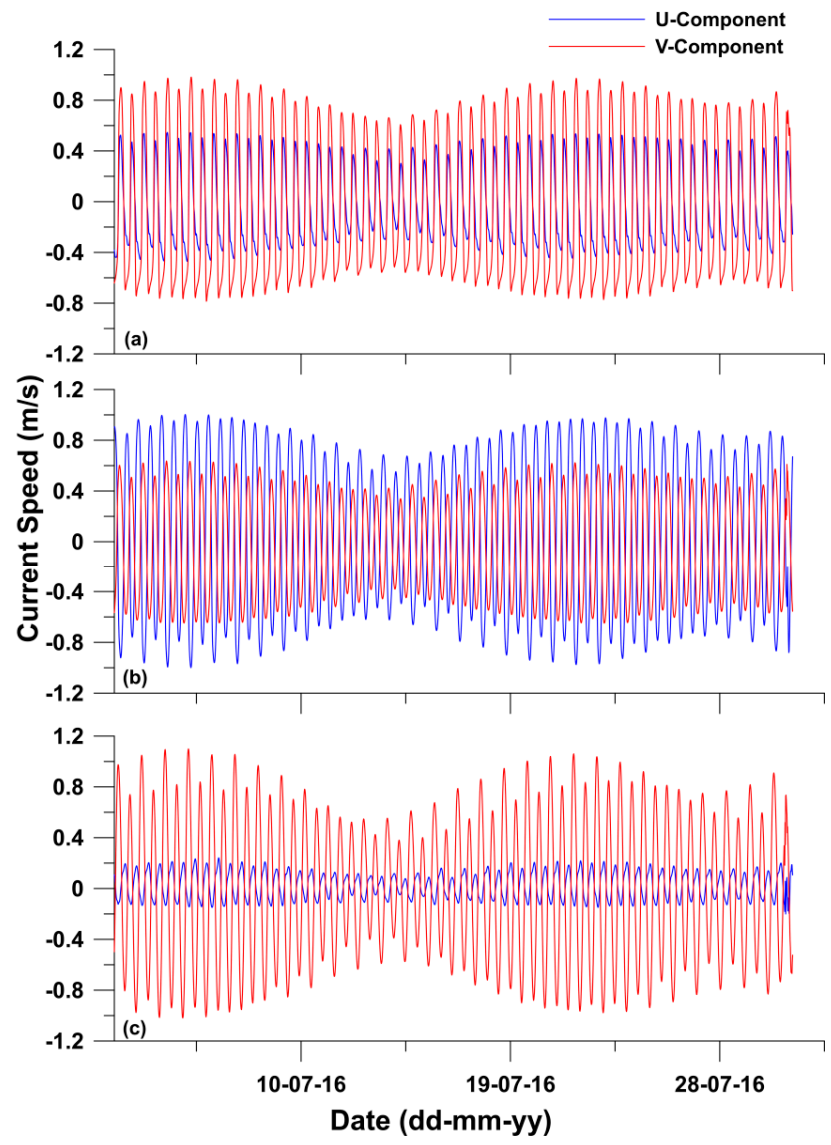

Figure 11. Simulated U-V component during SW-monsoon without river discharge at (a) central GoK, (b) Narmada mouth, and (c) southern GoK. 


\subsection{Lagrangian Circulation}

Lagrangian particle tracks were simulated by model forces through the combined action of tide and wind. Track results were obtained by the simulation of one month by releasing 237 particles in the model domain, among which 27 particle trails are presented in the figures. The track results revealed that after one month of simulation, none of the particles came out of GoK during the SW monsoon, except for a few from the southernmost portion of the Gulf (Figure 12). It can be noticed from the particle trajectories that the maximum distances were travelled by those that were released near to Dahej at the Narmada mouth due to the high current in the area. Particles that are released in the mouths of Sabarmati and Mahi River have a tendency to circulate at those particular locations. Particles released on the western coast of GoK have alongshore movement, and those from mid GoK have circulatory movements. The particles released near to Mumbai coast have alongshore movement as well.
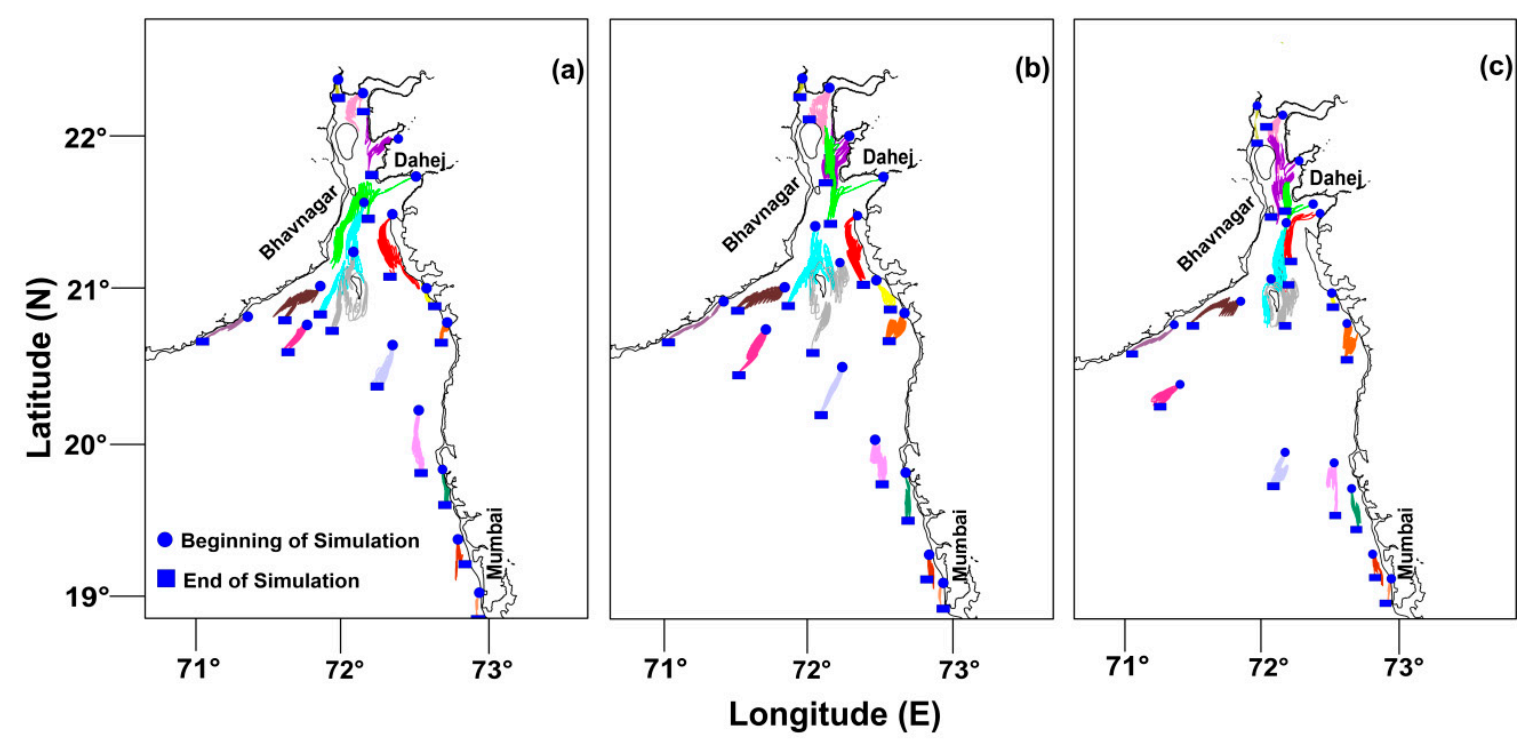

Figure 12. Lagrangian particle track results simulated for a one-month period during different seasons: (a) NE-monsoon, (b) pre-monsoon and (c) SW-monsoon. A total of 27 particle tracks in each season are represented. Particles released inside the Gulf have tendency to circulate there itself in different season.

The particle trajectories extracted for the NE monsoon also have similar tendencies, but the distances covered in this case are quite small. Particles released in the northern GoK, especially near to the mouths of Sabarmati and Mahi, could not come out of the northern part of the Gulf. Particles from mid GoK traversed further due to the high current speed. They mostly had circulatory motions, but particles released near to the coast had alongshore movement even in the eastern GoK, which is quite different from during the SW monsoon. Particle trajectories of the southern GoK were found to be small, and none of them came out of the Gulf after one month of simulation (Figure 12). Close to Mumbai, the particle trails were parallel to the coast. The trajectories were not very different in the case of the pre-monsoon. However, during the pre-monsoon season, the particles from the southern GoK had tendencies to move further downward, but none of the particles came out after one month of simulation. Particles released on either side of GoK near to the coastline exhibited circulatory movement. Particles released inside the Narmada estuary had alongshore movement and traversed to the northern GoK, depending on the tidal conditions. A particle released near to the Mahi estuary travelled across the Gulf and moved further southward, but could not escape. Particles released off Mumbai exhibited alongshore movement even in this case, and those released inside the gulf travelled larger distances than those released outside in each of the three seasons. 


\subsection{Residual Circulation}

The residual circulation during SW monsoon revealed two residual eddies inside the Gulf, in the western GoK and mid GoK (Figure 13a). Similar features are absent for the other two seasons, but residual eddy was identified in the mid GoK during the NE monsoon (Figure 13b). No residual eddy is noticed during the pre-monsoon season (Figure 13c). The maximum residual current speed is noticed inside the Gulf during the SW monsoon.
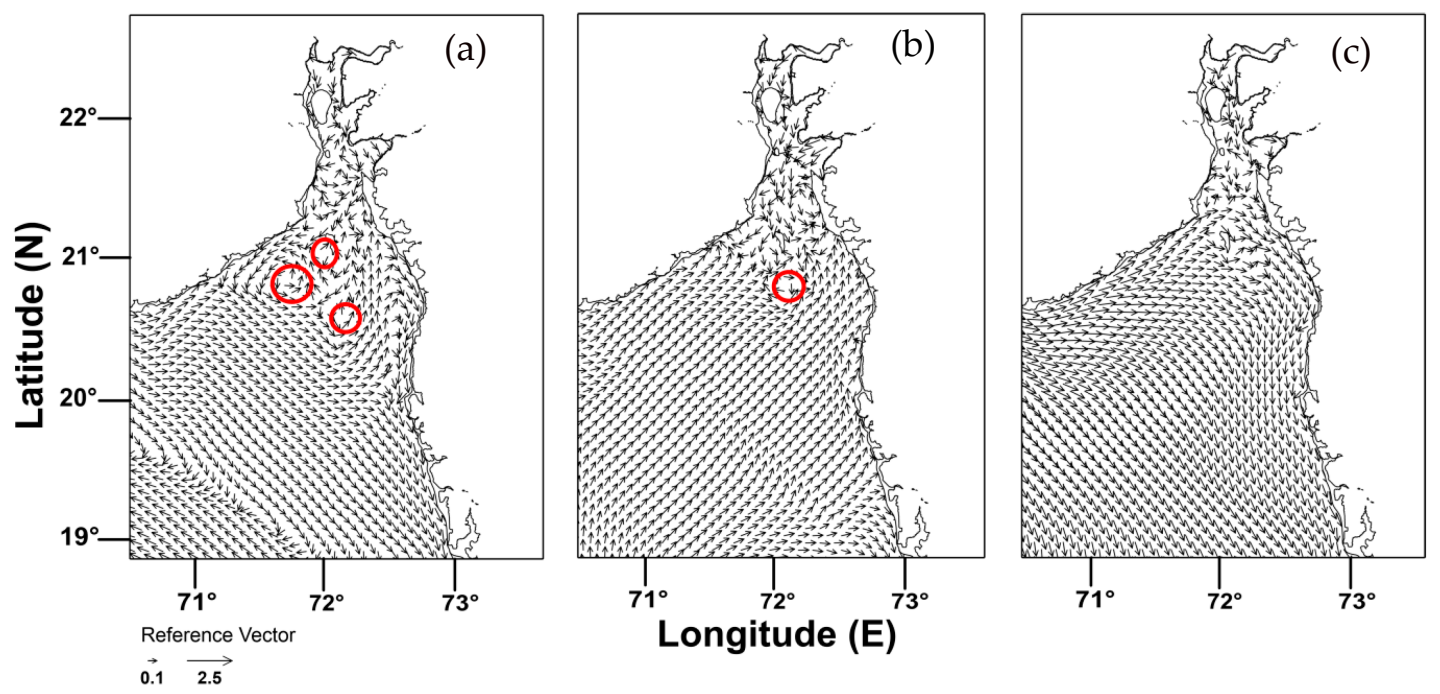

Figure 13. Residual circulation simulated during (a) SW-monsoon, (b) NE-monsoon, and (c) pre-monsoon, where the red line denotes the residual eddies.

\section{Discussion}

The GoK is basically a not-so-simple system with extreme tidal conditions, river discharges and wind impacts. The tidal height is at its maximum near to Bhavnagar, which is associated with the maximum current speed of more than $3 \mathrm{~m} / \mathrm{s}$. This behaviour of tidal amplification is attributed to resonance, which is a function of geometry and bottom friction [2,29]. Thus, it could be inferred that the current speed in this area is modulated by the tidal amplitude as well as the local geometry effects. The very simplistic depth-averaged numerical model predicted the tidal amplitude, as well as the amplitude of the current speed, quite accurately, although minute variation in the predicted and observed phase was obtained. Maximum current speed was obtained near to Dahej and Bhavnagar in each season by the model simulation. The barotropic circulation of the model domain reveals that although GoK is directly connected to the Arabian Sea, there is a prominent dissimilarity between the circulation of the Gulf and the open sea. A barrier-like formation in the southern GoK demonstrates this difference. This result is well-reflected even in the Lagrangian Tracks, where the particle trails of GoK are confined there themselves. Although the barrier formation is a seasonal phenomenon, it could be associated with the mixing characteristics of GoK. It has been hypothesised that this type of barrier formation is mostly associated with the bathymetry of the region, which is purely a regional phenomenon $[30,31]$. It should also be noted that the minimal exchange of water-mass between the Arabian Sea and GoK could also be a result of this kind of formation $[32,33]$ which would be the future aspect of the study. The barrier formation is associated with the topography of the Gulf, as well as the tidal currents, and this phenomenon can be well reflected in a schematic diagram (Figure 14), where it is shown that due to high flood current, water could overcome the barrier and enter GoK, but during the ebb period, the water exchange between GoK and AS is hampered. During the ebb condition, there was mainly a noticeable barrier, while during flood, this was either vague or absent. During pre-monsoon season, the barrier was noticed for both tidal conditions. Thus, it can be surmised that due to the high flood current speed, the whole water parcel surrounding GoK goes inside the Gulf, 
but due to the comparatively smaller ebb current speed, the Gulf restricts the water exchange with the north-eastern Arabian Sea during ebb, hence forming a barrier. This would not only restrict the water mass from coming out, but also the suspended sediment and anthropogenic wastes, which could have direct/indirect impacts on the biological community of the Gulf. The treated effluent discharged by the industries present on either bank of the Gulf will affect the Gulf ecology, since the Gulf has a tendency to accumulate particles, which could include suspended sediment, pollutants, industrial or domestic wastes, oil spill, etc. The alongshore component of the current dominated in the northern and western Gulf, but the dominance of the cross-shore component of the current was identified in the eastern GoK at the Narmada mouth, which is due to the influence of the Narmada river discharge into the sea. The influence of the river could be seen up to a distance of $13 \mathrm{~km}$ from the river mouth on average, and its impact was found to be purely localised. The Lagrangian track results revealed that the particles released inside the Gulf had a tendency to circulate there, and did not leave the system. These trajectories revealed that the maximum distances were travelled by those particles released around Mal Bank Island in the central GoK. This is due to the strong current in the central portion of the Gulf [34]. The presence of eddy structures around the Mal Bank and Piram Island is reflected well in the track results. Thus, it can be surmised on the basis of the track results that GoK traps particles for more than a month. Even if the particles move towards the southern GoK, they cannot escape the system. The Lagrangian circulation well captures the Gulf's behaviour of accumulating particles. The study by Salim et al. [35] reinforced this behaviour of the Gulf, whereby they inferred that the coastal current prevents direct flushing of high chlorophyll a-rich water from GoK into the Arabian Sea; as a result, high chl a water accumulates inside GoK. The results from the present study are compared with another tropical macrotidal regime, viz., the Gulf of California, which is also a converging channel of the western United States. The latitudinal positions of both Gulfs are similar and both possess similar tidal characteristics (mixed-semi diurnal tide). Due to the similarity in their hydrodynamic properties, especially the Lagrangian Circulation [36], a comparison was made between the results of the present study and the studies carried out in the Gulf of California. The Lagrangian properties of particles studied in the Gulf of California by a 3D numerical model implied that due to the strong current in the eastern and southern Gulf, particle advections were greater, and the particles were trapped in the northern Gulf [37], which could be comparable with GoK. Surface circulation of the Gulf of California was studied simultaneously by 2D and 3D numerical models, and the study revealed that in the central Gulf, where the currents are stronger, the 2D and 3D horizontal advections were similar [12]. The semi-annual characteristics of the Lagrangian circulation of GoK are due to the variability of the hydrographic forcing of the numerical model. However, it can be seen that the circulation of GoK is mainly driven by the tidal forcing rather than the atmospheric forcing. Gutierrez et al. [36] studied the seasonal circulation of the Gulf of California from a Lagrangian point of view, and they concluded that the Gulf circulation was dominated by the presence of seasonal cyclonic and anti-cyclonic gyres. They inferred that the Lagrangian circulation had semi-annual characteristics due to hydrographic forcing of the numerical model, and established in their study that the northern region of the Gulf captured more particles after one month of simulation, which is similar to the present work, where the particles released near to the mouths of Sabarmati and Mahi river only circulated there. The core of the seasonal coastal current along the west coast of India is located on the shelf break, which could exert some influence on the circulation of GoK [38]. Thus, the wind forcing of this region was taken into consideration. The time series data at the three locations of the Gulf suggested a considerable riverine influence on eastern GoK, and as a result, the U-component of the current speed dominated in that region in each of the three seasons, which was found in a limited area of extent and did not influence the Gulf circulation as a whole. During the SW-monsoon, a considerable difference between the tidal current and combined tide and wind-driven current was noticed, which is due to the presence of monsoonal winds. Due to weak wind forcing during the other two seasons, this difference is quite negligible. In a nutshell, the results indicate that even though there is an effect of atmospheric forcing on the circulation of GoK, it is mostly driven by tidal forcing. There are residual eddies present inside 
the Gulf, which might act like systems to trap the particles inside GoK, and these flows exhibit great asymmetry with respect to the flood and ebb flow of the Gulf. The seasonal barrier, formed by the combined action of tide and bathymetry could be of serious concern as it isolates the Gulf from the surroundings during ebb condition. Thus, suspended sediment, effluents or any anthropogenic waste could be accumulated inside GoK, which could be a serious threat to the aquatic organisms.

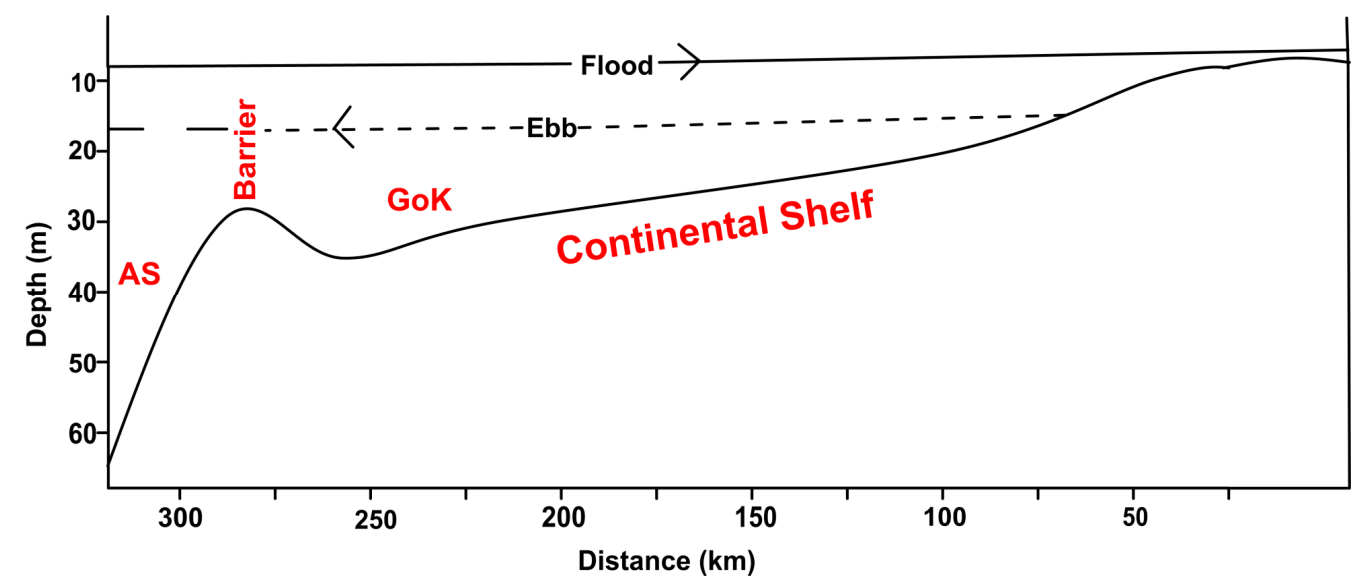

Figure 14. Schematic figure showing the formation of the barrier due to the combined action of bathymetry and tide, where water enters the Gulf due to high flood current speed but the barrier restricts the water exit during ebb.

\section{Conclusions}

The Lagrangian circulation of the Gulf of Khambhat was simulated using a 2D numerical model for three seasons, viz., pre-monsoon, monsoon, and post-monsoon. The model results depicted the presence of residual eddies inside the Gulf during SW monsoon. The Lagrangian track results showed that the particles released inside the Gulf do not leave the system except for a few from southern GoK. This could be associated with the presence of residual eddies, which do not allow particles to leave the Gulf. The combined tide and wind-driven circulation of GoK showed that though the two systems were connected, and that there was a clear dissimilarity between the Gulf circulation with that of the Arabian Sea. The present work infers that tidal domination is greater in GoK than any other physical force. As the Gulf restricts water parcel exchange with the Arabian Sea, the present study manifests a serious concern on the Gulf health in future. Future work will concentrate on the suspended sediment transport as well as the mixing characteristics of the GoK, a highly turbid water body of the west coast of India.

Author Contributions: Conceptualization, A.M.; methodology, A.M.; software, V.S.N.; validation, A.M. and V.S.K.; formal analysis, A.M.; investigation, A.M.; resources, V.S.K.; writing-original draft preparation, A.M.; writing — review and editing, V.S.K.; supervision, V.S.K.; All authors have read and agreed to the published version of the manuscript.

Funding: This research received no external funding.

Acknowledgments: Director, CSIR-National Institute of Oceanography, Goa encouraged carrying out the study. We thank all colleagues for the help provided during the field data collection. We thank the reviewers for the suggestions which improved the scientific content of this paper. This is an NIO contribution 6482, and forms a part of the Ph.D. thesis of the first author, registered at Bharathidasan University, Tiruchirappalli. The first author wishes to acknowledge Council of Scientific \& Industrial Research, New Delhi for the award of a Senior Research Fellowship.

Conflicts of Interest: The authors declare no conflict of interest.

Data Availability Statement: The current and tide data used for model validation and the model results generated under this study are available from the corresponding author by request. 


\section{References}

1. Giardino, A.; Elias, E.; Arunakumar, A.; Karunakar, K. Tidal modelling in the Gulf of Khambhat based on a numerical and analytical approach. Indian J. Geo-Mar. Sci. 2014, 43, 1253-1259.

2. Nayak, R.K.; Shetye, S.R. Tides in the Gulf of Khambhat, West Coast of India. Estuar. Coast. Shelf Sci. 2003, 57, 249-254. [CrossRef]

3. Joseph, A.; Vijaykumar, K.; Prakash, M.; Unnikrishnan, A.S.; Sundar, D.; Prabhudeasi, R.G. Observed tides at Mumbai High offshore region near the continental shelf break in the eastern Arabian Sea. Curr. Sci. 2009, 96, 1233-1235.

4. Anonymous. Indian Tide Table; Indian and Selected Foreign Ports; Survey of India, Government of India: Dehradun, India, 2017.

5. Sanil Kumar, V.; Ashok, K. Waves and Currents in Tide-dominated location off Dahej, Gulf of Khambhat, India. Mar. Geod. 2010, 33, 218-231. [CrossRef]

6. Anonymous. Comprehensive Marine EIA for Proposed Lignite Based 500 MW Power Plant at Ghogha by Bhavnagar Energy Company Limited 2013; NIO/SP-46/2013; Bhavnagar Energy Company Limited: Gujarat, India, 2013.

7. Morgan-King, T.L.; Schoellhamer, D.H. Suspended sediment flux and retention in a backwater tidal slough complex near the landward boundary of an estuary. Estuaries Coasts 2013, 36, 300-318. [CrossRef]

8. Gujarat Ecology Commission (GEC). Ecological Profile of Gujarat Talukas around Gulf of Khambhat 2011; Ecology Commission, Government of Gujarat: Gujarat, India, 2011.

9. Srivastava, P.S.; John, V.C. Current regime in the Gulf of Kutch. Indian J. Mar. Sci. 1977, 6, 39-48.

10. Unnikrishnan, A.S.; Shetye, S.R.; Michael, G.S. Tidal propagation in the Gulf of Khambhat, Bombay High and surrounding areas. Proc. Indian Acad. Sci. Earth Planet. Sci. 1999, 108, 155-177.

11. Nayak, R.K.; Salim, M.; Mitra, D.; Sridhar, P.N.; Mohanty, P.C.; Dadhwal, V.K. Tidal and Residual Circulation in the Gulf of Khambhat and its Surrounding on the West Coast of India. J Indian Soc. Remote Sens. 2015, 43, 151-162. [CrossRef]

12. Marinone, S.G. A numerical simulation of the two and three-dimensional Lagrangian circulation in the northern Gulf of California. Estuar. Coast. Shelf Sci. 2006, 68, 93-100. [CrossRef]

13. Sheng, J.; Wang, L. Numerical study of tidal circulation and nonlinear dynamics in Lunenburg Bay, Nova Scotia. J. Geophys. Res. 2004, 109, C10018. [CrossRef]

14. Allahdadi, M.N.; Jose, F.; Eurico, J.D.; Dong, S.K. Effect of wind, river discharge, and outer-shelf phenomena on circulation dynamics of the Atchafalaya Bay and shelf. Ocean Eng. 2017, 129, 567-580. [CrossRef]

15. Lou, J.; Ridd, P.V. Modeling of suspended sediment transport in coastal areas under waves and currents. Estuar. Coast. Shelf Sci. 1997, 45, 1-16.

16. Tattersall, G.R.; Elliott, A.J.; Lynn, N.M. Suspended sediment concentration in the Tamar estuary. Estuar. Coast. Shelf Sci. 2003, 57, 679-688. [CrossRef]

17. Longuet-Higgins, M.S. On the transport of mass by time-varying ocean currents. Deep-Sea Res. 1969, 16, 431-447. [CrossRef]

18. Muller, H.; Blanke, B.; Dumas, F.; Fand, L.; Mariette, V. Estimating the Lagrangian residual circulation in the Iroise Sea. J. Mar. Syst. 2009, 78, S17-S36. [CrossRef]

19. Van Sebille, E.; Griffies, S.M.; Abernathey, R.; Adams, T.P.; Berloff, P.; Biastoch, A.; Deleersnijder, E. Lagrangian ocean analysis: Fundamentals and practices. Ocean Model. 2018, 121, 49-75. [CrossRef]

20. Stoker, J.J. Water Waves; Interscience Publishers: New York, NY, USA, 1957.

21. Naidu, V.S.; Sarma, R.V. Numerical modeling of tide-induced currents in Thane creek, west coast of India. J. Waterw. Port Coast. Ocean Eng. 2001, 127, 241-244. [CrossRef]

22. Naidu, V.S.; Thomas, J.; Bari, S.; Kachave, S. The impact of dredging on residence time in the Amba estuary, west coast of India. Environ. Earth Sci. 2016, 75, 108.

23. Leendertse, J.J. A Water-Quality Simulation Model for Well-Mixed Estuaries and Coastal Seas: Volume I; Principles of Computation; The Rand Corporation: Santa Monica, CA, USA, 1970.

24. Egbert, G.D.; Erofeeva, S.Y. Efficient inverse modelling for barotropic ocean tides. J. Atmos. Ocean. Technol. 2002, 19, 183-204. [CrossRef]

25. Sathish, K.S.; Balaji, R. Effect of bottom friction on tidal hydrodynamics along Gulf of Khambhat, India. Estuar. Coast. Shelf Sci. 2015, 154, 129-136. [CrossRef] 
26. Kalnay, E.; Kanamitsu, M.; Kistler, R.; Collins, W.; Deaven, D.; Gandin, L.; Zhu, Y. The NCEP/NCAR 40-year reanalysis project. Bull. Am. Meteor. Soc. 1996, 77, 437-471. [CrossRef]

27. Gong, W.P.; Shen, J.; Jia, J.J. The impact of human activities on the flushing properties of a semi-enclosed lagoon: Xiaohai, Hainan, China. Mar. Environ. Res. 2008, 65, 62-76. [CrossRef] [PubMed]

28. Batten, W.M.J.; Bahaj, A.S.; Molland, A.F.; Chaplin, J.R. The prediction of hydrodynamic, performance of marine current turbines. Renew. Energy 2008, 33, 1085-1096. [CrossRef]

29. Shetye, S.R. Dynamics of circulation of the waters around India. In Ocean Science: Trends and Future Directions; Somayajulu, B.L.K.Y., Ed.; Indian National Science Academy: New Delhi, India, 1999; pp. 1-21.

30. Balasubramanya, T.N. A New Dynamic Feature of Wind-driven Ocean Circulations. Clim. Model. 2015, 86-87.

31. Gille, S.T.; Metzger, E.J.; Tokmakian, R. Seafloor Topography and Ocean Circulation. Spec. Issue Bathymetr. Space 2004, 17, 47-54. [CrossRef]

32. Chu, P.C.; Liu, Q.Y.; Jia, Y.L.; Fan, C.W. Evidence of a Barrier Layer in the Sulu and Celebes Seas. J. Phys. Oceanogr. 2002, 32, 3299-3309. [CrossRef]

33. Kara, B.A.; Peter, A.R.; Harley, E.H. Mixed layer depth variability and barrier layer formation over the North Pacific Ocean. J. Geophys. Res. 2000, 105, 783-801. [CrossRef]

34. Sinha, P.C.; Jena, G.K.; Jain, I.; Rao, A.D.; Lokman, H.M. Numerical Modelling of Tidal Circulation and Sediment Transport in the Gulf of Khambhat and Narmada Estuary, West Coast of India. Pertanika J. Sci. Technol. 2010, 18, 293-302.

35. Salim, M.; Nayak, R.K.; Mohanthy, P.C.; Sasamal, S.K.; Dadhwal, V.K.; Dutt, C.B.S.; Rao, M.S. Characterization of the Seasonal Circulation Patterns and Its Application on Oil Spill Transportin the Northwestern Continental Shelf of India. Mar. Geod. 2015, 38, 241-260. [CrossRef]

36. Gutierrez, O.Q.; Marinone, S.G.; Pares-Sierra, A. Lagrangian surface circulation in the Gulf of California from a 3D numerical model. Deep-Sea Res. Ii 2004, 51, 659-672. [CrossRef]

37. Marinone, S.G.; Lavin, M.F.; Pares-Sierra, A. A quantitative characterization of the seasonal Lagrangian circulation of the Gulf of California from a three-dimensional numerical model. Cont. Shelf Res. 2011, 31, 1420-1426. [CrossRef]

38. Shetye, S.R.; Gouveia, A.D.; Shenoi, S.S.C.; Sundar, D.; Michael, G.S.; Almeida, A.M.; Santanam, K. Hydrography and circulation off the west coast of India during the Southwest Monsoon 1987. J. Mar. Res. 1990, 48, 359-378. [CrossRef]

(C) 2020 by the authors. Licensee MDPI, Basel, Switzerland. This article is an open access article distributed under the terms and conditions of the Creative Commons Attribution (CC BY) license (http://creativecommons.org/licenses/by/4.0/). 